\title{
Technological Breakthrough for the Afforestation of Populus euphratica in the Mu Us Desert in China
}

\author{
Fei Tuo ${ }^{1}$, Beibei Gao ${ }^{2}$ and Zhibao Dong ${ }^{3, *}$ \\ 1 Greening Committee Office of Forestry Bureau of Yulin City, Yulin 719000, China; Feituo1966@163.com \\ 2 Department of Pesticide Science, College of Plant Protection, Nanjing 210095, China; gaob@njmu.edu.cn \\ 3 School of Geography and Tourism, Shaanxi Normal University, Xi' an 710062, China \\ * Correspondence: zbdong@snnu.edu.cn; Tel.: +86-139-1946-8009
}

Citation: Tuo, F.; Gao, B.; Dong, Z. Technological Breakthrough for the Afforestation of Populus euphratica in the Mu Us Desert in China. Sustainability 2021, 13, 13900. https://doi.org/10.3390/su132413900

Academic Editors: Baojie He, Ayyoob Sharifi, Chi Feng and Jun Yang

Received: 4 December 2021

Accepted: 10 December 2021

Published: 16 December 2021

Publisher's Note: MDPI stays neutral with regard to jurisdictional claims in published maps and institutional affiliations.

Copyright: (c) 2021 by the authors. Licensee MDPI, Basel, Switzerland. This article is an open access article distributed under the terms and conditions of the Creative Commons Attribution (CC BY) license (https:/ / creativecommons.org/licenses/by/ $4.0 /)$.

\begin{abstract}
The Mu Us Desert (MUD) is one of the four largest sandy lands in China. On 22 April 2020, the Shaanxi Forestry Bureau announced that the desertification land control rate in Yulin reached $93.24 \%$, which means that the Mu Us Desert was about to "disappear" from the territory of Shaanxi. However, the problem of biological diversity, mostly for Pinus sylvestris and shrubs in the Mu Us Desert, remains serious. In order to consolidate the current forest conservation efforts, Populus euphratica has been considered an ideal candidate since the 1950s. However, the low survival rate and conservation rate of Populus euphratica in the MUD led us to perform further large-scale introduction for over 70 years. In this study, by using root control seedling technology, the survival and the conservation rate of Populus euphratica were increased to more than $90 \%$. This study makes possible the introduction of Populus euphratica in the MUD, and the successful introduction of Populus euphratica will provide a new barrier for forest ecosystem stability in the desertification control project in the Yulin area.
\end{abstract}

Keywords: biological diversity; Yilin; grafting; cutting seedling; nutrition pot seedlings

\section{Introduction}

The Mu Us Desert (MUD), located between the Yulin area of Shaanxi province and Ordos City in the Inner Mongolia Autonomous Region, covers an area of 42,200 square kilometers $\left(37^{\circ} 27.5^{\prime} \mathrm{N}-39^{\circ} 22.5^{\prime} \mathrm{N}, 107^{\circ} 20^{\prime} \mathrm{E}-111^{\circ} 30^{\prime} \mathrm{E}\right)$ [1-3]. This region has a typical temperate, semi-arid, continental monsoon climate with a large temperature difference between day and night. The annual average temperature in the MUD is $8.3-10.1{ }^{\circ} \mathrm{C}$, and the extreme high temperature and the extreme low temperature are $42.8{ }^{\circ} \mathrm{C}$ and $-31.8{ }^{\circ} \mathrm{C}$, respectively [4]. The freezing period here always lasts over 5 months, the maximum freezing depth is $140 \mathrm{~cm}$, the annual precipitation is $350 \sim 503 \mathrm{~mm}$, and the annual evaporation is $2000 \sim 2500 \mathrm{~mm}$. The annual wind speed is $3.24 \mathrm{~m} / \mathrm{s}$, the maximum wind strength is $9 \sim 10 \mathrm{~m} / \mathrm{s}$, and the annual wind days are 15 33 days, with a maximum of 77 days. The soil textures in the MUD are mainly chestnut soil and aeolian sand soil with low vegetation coverage [3].

Up to now, the main plant species for afforestation in the MUD have been Pinus sylvestris, Hedysarum scoparium, Hedysarum mongolicum, Hippophae rhamnoides, and Salixpsammophila. Pinus sylvestris, as the only arbor in this grassland reclamation, needs more company to stop the risk of secondary desertification [4,5]. However, the harsh natural conditions in Yulin make it difficult to introduce a new species [6]. In considering the common living environment and its strong vitality, Populus euphratica became the best candidate [7-9]. Populus euphratica is distributed all over the world, with natural forests in Eurasia and Africa [9,10]. In China, natural Populus euphratica forests are mainly distributed in Xinjiang and northwest Inner Mongolia [11,12]. By comparing the climatic and environmental conditions of the original place of Populus euphratica and the environmental conditions of Yulin, we found that the habitat conditions in Yulin were better [13]. Populus 
euphratica should have adapted to the habitat of Yulin and could be feasibly introduced in Yulin. However, during the last 70 years, all the attempts at Populus euphratica introduction in Yulin have failed [4].

In the meantime, there are also some small-scale natural Populus euphratica forests found in Yulin. In 2007, Pangyan Li discovered a pure natural Populus euphratica forest near Tongwancheng in Jingbian County in Yulin. This forest is about $1800-2000 \mathrm{~m}^{2}$, possessing 56 trees in total and aged no less than 50 years. These natural Populus euphratica forests confirmed that P. euphratica could be introduced successfully in Yulin. Tuo et al. (2020) found that the high death rate of Populus euphratica in Yulin could be associated with several specific pathogenic fungi, such as Alternaria alternata and Didymella glomerata [4]. Previous studies indicated that the plant-associated pathogenic microbial could be affected by the tissue age and vigor of the plant, which could act as the key factors for the plant's survival [14-16]. In this study, all the potential lethal factors like pathogenic fungi, seedling cultivation, and root breakdown were investigated to avoid the low survival and conservation rate of Populus euphratica afforestation in the MUD.

\section{Materials and Methods}

\subsection{Experimental Design}

In this study, factors such as the seedling sources, experimental sites, seedling specifications, land preparations, soil replacement, and management measures were investigated following the framework shown in Figure 1. In brief, this study started in 2017, and different seedlings from Xinjiang and Inner Mongolia were introduced at different experimental sites. In the meantime, sowing of seedlings, grafting, and cutting the seedlings were tried to explore the potential mechanism for the low survival rate. In addition, different land preparation, soil replacement, and management measures were compared.

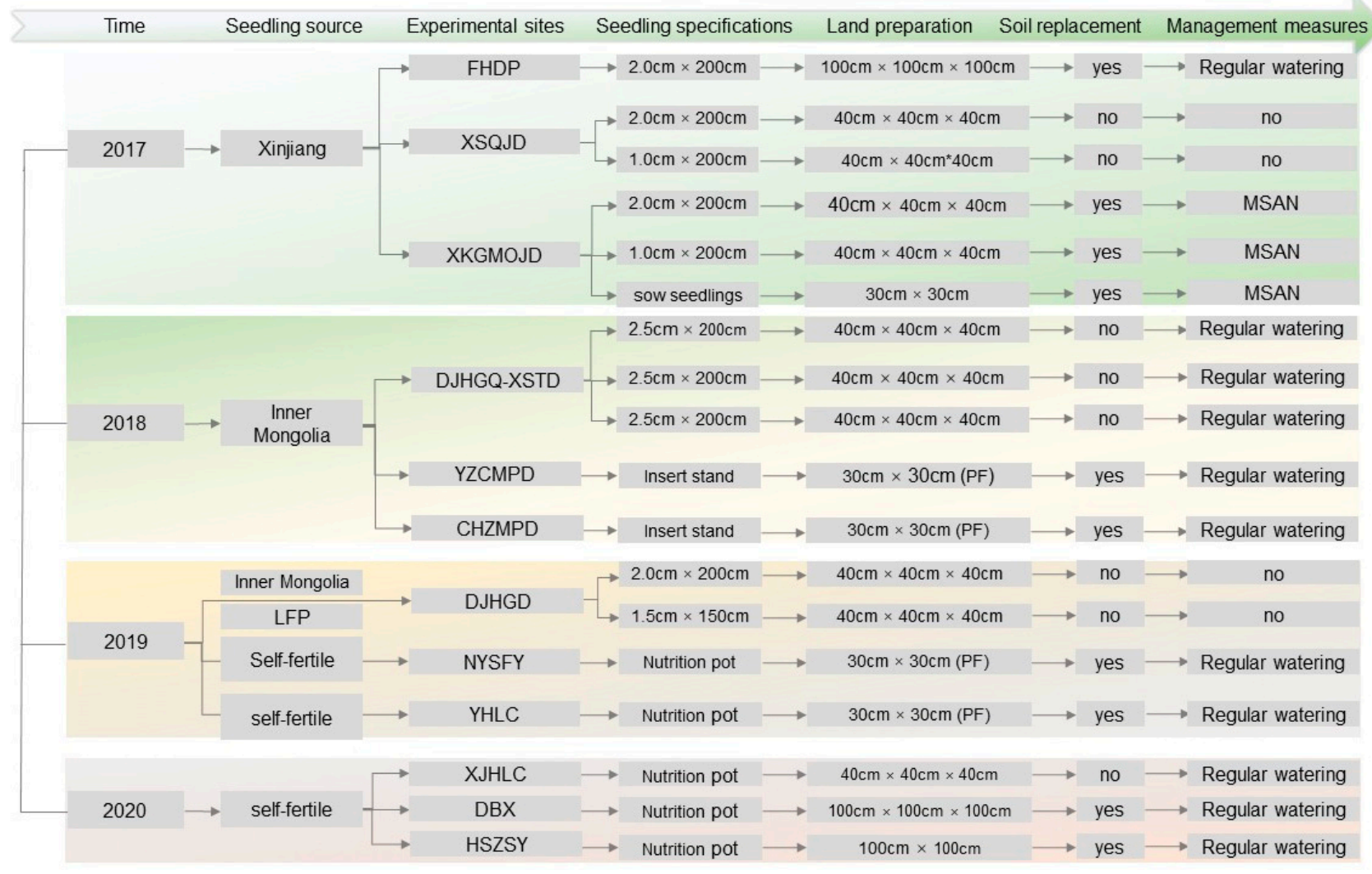

Figure 1. The framework of this study. 


\subsection{Experimental Sites and Source of Seedlings}

The experimental sites, seedling specifications, and test scale in different years are listed below (Figure 2). In 2017, 2000 strains (girth: $2 \mathrm{~cm}$, height: $200 \mathrm{~cm}$ ) 2000 strains (girth: $1 \mathrm{~cm}$, height: $200 \mathrm{~cm}$ ) +2000 strains (sown seedlings: 1 year) of Populus euphratica seedlings were introduced from Xinjiang Korla, Yulin County, 31 Regiment, China. These seedlings were planted in three different experimental sites of FHDP $\left(109^{\circ} 35^{\prime} 4.8408^{\prime \prime} \mathrm{E}\right.$, $\left.38^{\circ} 26^{\prime} 56.274^{\prime \prime} \mathrm{N}\right)$, XSQJD $\left(109^{\circ} 44^{\prime} 29.82^{\prime \prime} \mathrm{E}, 38^{\circ} 17^{\prime} 27.19^{\prime \prime} \mathrm{N}\right)$, and XKGMPJD $\left(109^{\circ} 41^{\prime} 9.2^{\prime \prime}\right.$ E, $38^{\circ} 9^{\prime} 37.7^{\prime \prime} \mathrm{N}$ ). In 2018, 5700 strains (girth: $2.5 \mathrm{~cm}$, height: $200 \mathrm{~cm}$ ) of Populus euphratica seedlings were introduced from Inner Mongolia, Front Banner, China. These seedlings were planted in DJHGQ-XSTD $\left(109^{\circ} 41^{\prime} 15.3^{\prime \prime} \mathrm{E}, 38^{\circ} 21^{\prime} 50.6^{\prime \prime} \mathrm{N}\right)$. Another 900 strains of self-fertile cutting seedlings were planted in YZCMPD $\left(109^{\circ} 37^{\prime} 18.7^{\prime \prime} \mathrm{E}, 38^{\circ} 25^{\prime} 58.2^{\prime \prime} \mathrm{N}\right)$ and CHZMPD (109 $\left.51^{\prime} 38.9^{\prime \prime} \mathrm{N}, 38^{\circ} 37^{\prime} 34.1^{\prime \prime} \mathrm{E}\right)$ amounting to 300 strains and 600 strains, respectively. In 2019, three experimental sites in DJHGD $\left(109^{\circ} 41^{\prime} 15.3^{\prime \prime} \mathrm{E}, 38^{\circ} 21^{\prime} 50.6^{\prime \prime} \mathrm{N}\right)$, NYSFY $\left(109^{\circ} 47^{\prime} 37.1^{\prime \prime} \mathrm{E}, 38^{\circ} 23^{\prime} 2.5^{\prime \prime} \mathrm{N}\right)$, and YHLC $\left(109^{\circ} 51^{\prime} 40.1^{\prime \prime} \mathrm{E}, 38^{\circ} 0^{\prime} 38.0^{\prime \prime} \mathrm{N}\right)$ were chosen for the self-fertile seedlings (171,000 strains), local field planting seedlings (1900 strains), and seedlings from Inner Mongolia, Front Banner (15,000 strains). In 2020, self-fertile seedlings $\left(70,000\right.$ strains) were planted in XJHLC $\left(109^{\circ} 41^{\prime} 15.3^{\prime \prime} \mathrm{E}, 38^{\circ} 21^{\prime} 50.5^{\prime \prime} \mathrm{N}\right)$, DBX $\left(107^{\circ} 32^{\prime} 32.9^{\prime \prime} \mathrm{E}, 37^{\circ} 35^{\prime} 52.1^{\prime \prime} \mathrm{N}\right)$, and HSZSY $\left(109^{\circ} 43^{\prime} 58.4^{\prime \prime} \mathrm{E}, 38^{\circ} 2^{\prime} 12.3^{\prime \prime} \mathrm{N}\right)$.

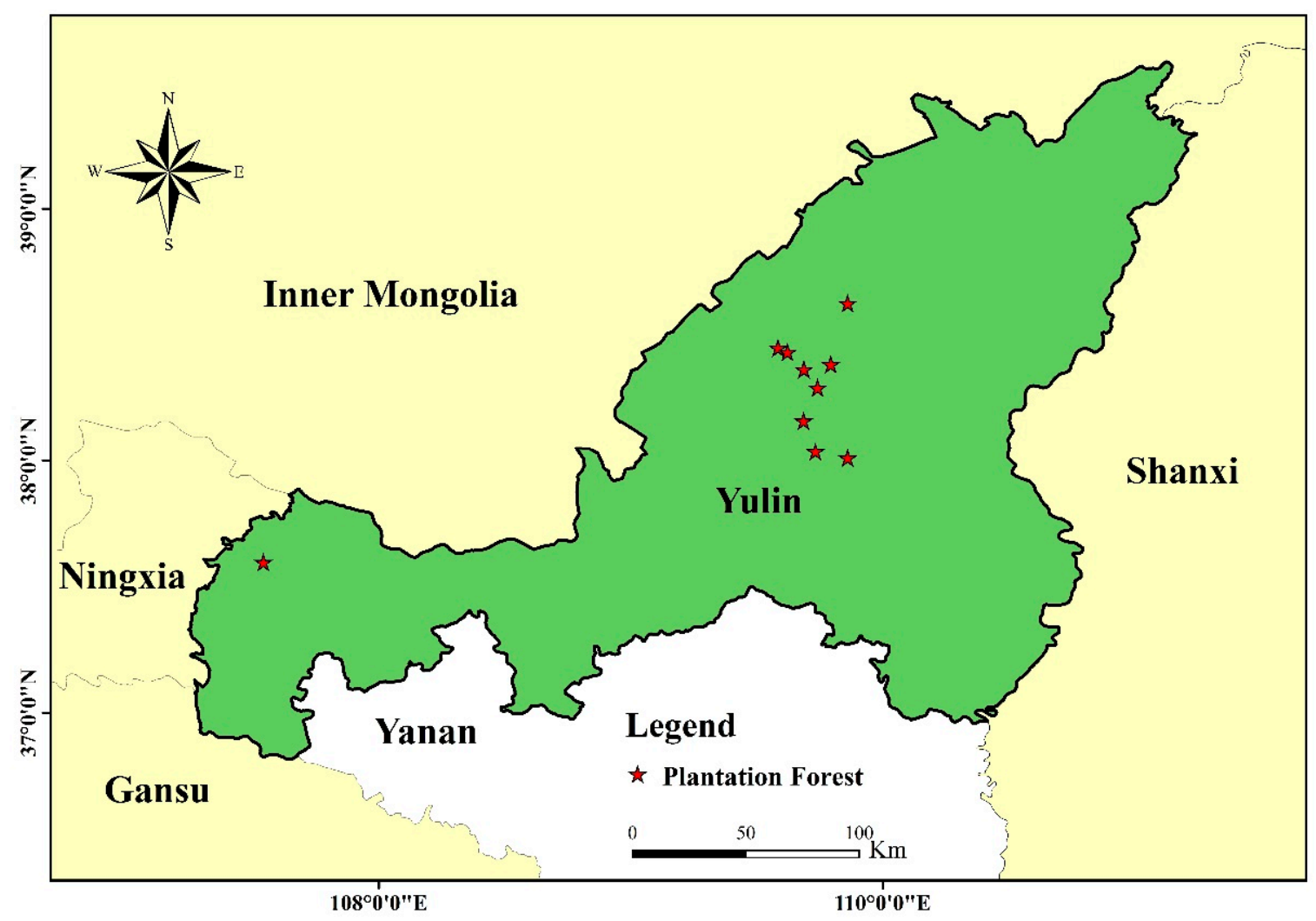

Figure 2. Afforestation test sites.

\subsection{The Method of Grafting and Cutting Seedlings}

The cut Populus euphratica seedlings were grafted with Populus alba var. pyramidalis Bge. as rootstock. In the grafting experiment, two kinds of grafting heights were designed according to the distance between the grafting port and the ground. The height of the short grafting port from the ground was $50 \mathrm{~cm}$, and the height of the top-working port from the ground was $110 \mathrm{~cm}$.

The Populus euphratica cuttings with a 1-year age for the mother plants were chosen for the cutting seedling experiment. Different stem diameters of the cuttings $(<5 \mathrm{~mm}$, 5-10 $\mathrm{mm}$, and $>10 \mathrm{~mm}$ ) were investigated. 


\subsection{The Method for the Self-Fertile Seedling Raising}

The Populus euphratica seeds were taken from female mother trees with ages of 10-15 years. The mother trees possessed good site conditions, healthy growth, consistent leaf colors, full ears, no dry branches, and no pests or diseases.

Populus euphratica seeds vary greatly in maturity due to individual differences and different natural environments. Generally, they mature from June to August. When the capsule skin turns from green to yellow, the capsule cracks, and the seed is fleshy red, indicating that the seed is mature. During seed harvesting, the maturing ears were selected and collected in time before falling off after maturity. The collected ears were dried out in a ventilated and dry house with a thickness of 5-10 cm and turned up and down 3-4 times a day. To prevent ear fever mildew, artificial threshing was conducted when the rate of capsule cracking flocculation reached $70 \%$. The seeds were threshed with a fine screen to remove impurities. After that, the seeds were dried out in a ventilated and dry house with a thickness of 2-3 cm and turned up and down 3-4 times a day.

In order to ensure the viability of the seeds, the processed seeds were packaged and stored in time. Calcium chloride was used as a desiccant for bottling, and wax was used to seal the mouth of the bottle. The seeds were stored at $4{ }^{\circ} \mathrm{C}$.

Before sowing, the seeds were disinfected with a $0.1-0.5 \%$ potassium permanganate solution for 10-20 $\mathrm{min}$. After that, the seeds were taken out and rinsed with water. Then, they were soaked in cold water for $2 \mathrm{~h}$ and mixed 20 times (at a volume ratio) with fine sand before sowing.

Previous work indicated that the seeds of Populus euphratica are small, their bud unearthing ability is poor, and the seedling stage is not salt tolerant $[9,10]$. Therefore, the light loam or sandy loam were chosen as the breeding ground, and the seedling experiments were carried out in greenhouses. Before sowing, the seedling grounds were irrigated with plantar water, and then $2-3 \mathrm{~m}^{3}$ of organic fertilizer was applied per $667 \mathrm{~m}^{2}$. In the meantime, $20 \mathrm{~kg}$ per $667 \mathrm{~m}^{2}$ calcium superphosphate, $50 \mathrm{~kg}$ per $667 \mathrm{~m}^{2}$ ferrous sulfate, and deep cultivation of 20-30 cm were applied. In addition, grass roots, stones, and other debris were removed. In this study, Populus euphratica seedlings were planted in the bed-type seedling grounds. The size of the seedling bed was $1 \mathrm{~m}$ wide and $15 \mathrm{~m}$ long, and the bed between the footpath's width was about $40 \mathrm{~cm}$.

The Populus euphratica seeds were scattered in the seedbed after the seeds were mixed thoroughly with sand. The seeds were planted evenly with a seeding density of $350-400 \mathrm{~g} / \mathrm{mu}$ and then covered slightly with fine sand. The seedbeds were sprayed in time after sowing.

\subsection{Management Measures}

\subsubsection{Soil Water Management}

The moist seedling beds were kept at $60 \%$ during the seedling period using sprinkler irrigation. After emergence, considering the weakness of the drought resistance ability of the seedlings, a "more frequency less quantity" irrigation method was conducted to ensure the water demand of the seedlings. In the fast-growing period, the watering cycles were extended, but the seedlings were irrigated thoroughly each time. In the later stage, the irrigation was controlled properly to promote the lignification of seedlings to improve the cold resistance for the upcoming winter.

\subsubsection{Scarification Weeding}

Before seedling germination of leaves, nitrofen (775 g.a.i./ha) was sprayed as the pre-seedling protection treatment. The first weeding was conducted artificially when the seedlings were all out to protect the seedlings from injury. The second and third weedings were carried out in conjunction with soil loosening, requiring protection of the seedling roots and aboveground parts from injury. 


\subsubsection{Fertilization}

Fertilizer at the seedling stage was mainly nitrogen fertilizer (inorganic fertilizer was applied at $4-5 \mathrm{~kg} / \mathrm{mu}$ ). The first instance of fertilization was applied 1 month after emergence of the seedlings. In the later period, the amount of fertilizer was appropriately increased with a frequency of once a month. The last time fertilization was conducted was 1 month before seedling transplantation.

\subsubsection{Extermination of Disease and Insect Pest}

In the seedlings' rapid growth period and later growth period, the strategy for disease, insect, and pest control adhered to a principle of "prevention in the first and integrating with control". The main diseases of Populus euphratica are leaf rust, brown spot, and blackspot, which could be protected by triadimefon combined with regular irrigation [4]. The major pest of Populus euphratica are Gryllotalpa spps. and Psyllidae, which could be stopped by poison bait made of trichlorfon and cottonseed cake.

\subsubsection{Seedling Protection}

After sowing, the young buds were shaded to prevent high temperatures and strong light from directly harming them. In the protected area, the ambient temperature was controlled, and the necessary spray cooling and ventilation cooling were prepared. The annual Populus euphratica seedlings are weak in terms of cold resistance. The cold protection after the arrival of winter was mainly to pay attention to the timely winter irrigation.

\subsubsection{Seedling Transplantation}

The annual seedlings were transplanted into a nutrition pot in the early spring of the next year. The Populus euphratica seedlings were irrigated thoroughly 3 days before transplantation. When transplanting, an oblique cut into the soil was made to truncate the taproot, which could promote the formation of the lateral fibrous roots. We then pressed down the substrate after planting the seedlings into the nutrition pot. The transplanted seedlings could be used for afforestation after $2-3$ years of cultivation.

\section{Results}

\subsection{Transplanting Experiment of Populus Euphratica Seedlings from Xinjiang}

In 2017, the Populus euphratica seedlings from Xingjiang were introduced with two different seedling specifications. The large-sized seedlings, with girths of $2.0 \mathrm{~cm}$ and heights of $200 \mathrm{~cm}$, were planted in three different sites (FHDP, XSQJD, and XKGMPJD) in April 2017. In the experimental sites of FHDP and XKGMPJD, the seedlings were transplanted with soil replacement and regular watering. The results shown in Table 1 indicate that the survival rate of the seedlings in the first year (year 1) were $41 \%$ and $58 \%$ for FHDP and XKGMPJD, respectively. After then, the conservation rates in the second, third, and fourth year decreased gradually, and the conservation rates in the fourth year were $8.4 \%$ and $2.0 \%$. The large-sized seedlings in XSQJD were planted with no soil replacement and no specific management measures. The results shown in Table 1 indicate that the survival rate in the first year was $68 \%$. However, the conservation rates in the second, third, and fourth year were $17 \%, 0 \%$, and $0 \%$, respectively.

The smaller-sized seedlings with a girth of $1.0 \mathrm{~cm}$ and height of $200 \mathrm{~cm}$ were planted in XSQJD and XKGMPJD in April 2017. In XSQJD, the smaller seedlings were planted with no soil replacement and no specific management measures. The results shown in Table 1 indicate that the survival rate in the first year was 35\%, and the conservation rate in the second, third, and fourth year were $18.4 \%, 0 \%$, and $0 \%$, respectively. In XKGMPJD, the smaller seedlings were transplanted with soil replacement and regular watering. The results shown in Table 1 indicate that the survival rate of the seedlings in the first year was $62 \%$. In the second, third, and fourth year, the conservation rates were $35 \%, 12 \%$, and $3 \%$, respectively. In addition, the sown seedlings in XKGMPJD were tested with regular soil replacement and watering. The results shown in Table 1 indicate that the survival rate 
of the sown seedlings in the first year was $98.0 \%$, and the conservation rate of the sown seedlings remained at $97.0 \%$ before the fourth year's transplantation.

Table 1. Investigation of the survival rate of Populus euphratica.

\begin{tabular}{|c|c|c|c|c|c|c|c|c|c|c|c|}
\hline $\begin{array}{l}\text { Experimental } \\
\text { Sites }\end{array}$ & $\begin{array}{l}\text { Planting } \\
\text { Time }\end{array}$ & $\begin{array}{c}\text { Seedling } \\
\text { Specifications }\end{array}$ & $\begin{array}{l}\text { Seedling } \\
\text { Source }\end{array}$ & Number & $\begin{array}{c}\text { Land } \\
\text { Preparation }\end{array}$ & $\begin{array}{c}\text { Soil } \\
\text { Replacement }\end{array}$ & $\begin{array}{l}\text { Management } \\
\text { Measures }\end{array}$ & $\begin{array}{c}\mathrm{SR}^{1} \\
\text { First Year (\%) }\end{array}$ & $\begin{array}{c}\mathrm{CR}^{2} \\
\text { Second Year (\%) }\end{array}$ & $\begin{array}{c}\mathrm{CR}^{2} \\
\text { Third Year (\%) }\end{array}$ & $\begin{array}{c}\mathrm{CR}^{2} \\
\text { Fourth Year (\%) }\end{array}$ \\
\hline FHDP & April 2017 & $\begin{array}{l}\text { girth } 2.0 \mathrm{~cm} \\
\text { height } 200 \mathrm{~cm}\end{array}$ & Xinjiang & 1600 & $\begin{array}{l}40 \mathrm{~cm} \times 40 \\
\mathrm{~cm} \times 40 \mathrm{~cm}\end{array}$ & yes & $\begin{array}{c}\text { regular } \\
\text { watering }\end{array}$ & 41.0 & 22.3 & 8.6 & 8.4 \\
\hline \multirow{2}{*}{ XSQJD } & \multirow{2}{*}{ April 2017} & $\begin{array}{l}\text { girth } 2.0 \mathrm{~cm}, \\
\text { height } 200 \mathrm{~cm}\end{array}$ & Xinjiang & 200 & $\begin{array}{l}40 \mathrm{~cm} \times 40 \\
\mathrm{~cm} \times 40 \mathrm{~cm}\end{array}$ & no & no & 68.0 & 17.0 & 0 & 0 \\
\hline & & $\begin{array}{l}\text { girth } 1.0 \mathrm{~cm}, \\
\text { height } 200 \mathrm{~cm}\end{array}$ & Xinjiang & 1000 & $\begin{array}{l}40 \mathrm{~cm} \times 40 \\
\mathrm{~cm} \times 40 \mathrm{~cm}\end{array}$ & no & no & 35.0 & 18.4 & 0 & 0 \\
\hline \multirow{3}{*}{ XKGMPJD } & \multirow{3}{*}{ April 2017} & $\begin{array}{l}\text { girth } 2.0 \mathrm{~cm} \\
\text { height } 200 \mathrm{~cm}\end{array}$ & Xinjiang & 200 & $\begin{array}{l}40 \mathrm{~cm} \times 40 \\
\mathrm{~cm} \times 40 \mathrm{~cm} \\
\end{array}$ & yes & MSAN $^{3}$ & 62.0 & 35.0 & 12.0 & 3.0 \\
\hline & & $\begin{array}{l}\text { girth } 1.0 \mathrm{~cm}, \\
\text { height } 200 \mathrm{~cm}\end{array}$ & Xinjiang & 1000 & $\begin{array}{l}40 \mathrm{~cm} \times 40 \\
\mathrm{~cm} \times 40 \mathrm{~cm}\end{array}$ & yes & $\mathrm{MSAN}^{3}$ & 58.0 & 23.0 & 5.0 & 2.0 \\
\hline & & $\begin{array}{c}\text { sown seedlings } \\
(1 \text { year) }\end{array}$ & Xinjiang & 2000 & $\begin{array}{c}30 \mathrm{~cm} \times 30 \\
\mathrm{~cm}\end{array}$ & yes & MSAN $^{3}$ & 98.0 & 97.0 & 97.0 & transplant \\
\hline
\end{tabular}

Note: ${ }^{1} \mathrm{SR}=$ survival rate; ${ }^{2} \mathrm{CR}=$ conservation rate; ${ }^{3} \mathrm{MSAN}$ : manage seedlings according to nursery.

\subsection{Transplanting Experiment of Populus Euphratica Seedlings from Inner Mongolia}

In 2018, the Populus euphratica seedlings from Inner Mongolia were introduced with specifications of a girth of $2.5 \mathrm{~cm}$ and height of $200 \mathrm{~cm}$. These seedlings were planted in DJHGQ in three different soil types of XSTD, SQYFP and SQLFP in April 2018. The seedlings were transplanted with no soil replacement and regular watering. The results shown in Table 2 indicate that the survival rates of the seedlings in the first year were $70 \%, 55 \%$, and $60 \%$, respectively. After that, the conservation rates in the second, third, and fourth years decreased gradually, and the conservation rates at the fourth year were $0 \%, 0 \%$, and $1.3 \%$. In the meantime, a cutting seedling experiment was conducted using seedlings from Inner Mongolia at YZCMPD. The results shown in Table 2 indicate that the survival rate in the first year was $18.2 \%$, and the conservation rate in the second, third, and fourth years were $11.2 \%, 10.0 \%$, and $10.0 \%$, respectively. In addition, a grafting test was conducted, and the cuttings were made from Inner Mongolia seedlings. In the grafting test, the survival rate in the first year and the conservation rate up to the fourth year stayed at $94.0 \%$.

Table 2. Investigation on the survival rate of Populus euphratica.

\begin{tabular}{|c|c|c|c|c|c|c|c|c|c|c|c|}
\hline $\begin{array}{l}\text { Experimental } \\
\text { Sites }\end{array}$ & $\begin{array}{l}\text { Planting } \\
\text { Time }\end{array}$ & $\begin{array}{c}\text { Seedling } \\
\text { Specifications }\end{array}$ & $\begin{array}{l}\text { Seedling } \\
\text { Source }\end{array}$ & Number & $\begin{array}{c}\text { Land } \\
\text { Preparation }\end{array}$ & $\begin{array}{c}\text { Soil } \\
\text { Replace- } \\
\text { ment }\end{array}$ & $\begin{array}{l}\text { Management } \\
\text { Measures }\end{array}$ & $\begin{array}{c}\text { SR }^{1} \\
\text { First Year (\%) }\end{array}$ & $\begin{array}{c}\mathrm{CR}^{2} \\
\text { Second Year (\%) }\end{array}$ & $\begin{array}{c}\mathrm{CR}^{2} \\
\text { Third Year (\%) }\end{array}$ & $\begin{array}{c}\mathrm{CR}^{2} \\
\text { Fourth Year (\%) }\end{array}$ \\
\hline $\begin{array}{l}\text { DJHGQ- } \\
\text { XSTD }\end{array}$ & April 2018 & $\begin{array}{l}\text { girths } 2.5 \mathrm{~cm} \text {, } \\
\text { heights } 200 \mathrm{~cm}\end{array}$ & $\begin{array}{c}\text { Inner } \\
\text { Mongolia }\end{array}$ & 2000 & $\begin{array}{c}40 \mathrm{~cm} \times 40 \\
\mathrm{~cm} \times \\
40 \mathrm{~cm}\end{array}$ & no & $\begin{array}{c}\text { regular } \\
\text { watering }\end{array}$ & 70.0 & 12.3 & 2.3 & 0 \\
\hline $\begin{array}{l}\text { DJHGQ- } \\
\text { SQYFP }\end{array}$ & April 2018 & $\begin{array}{l}\text { girths } 2.5 \mathrm{~cm} \text {, } \\
\text { heights } 200 \mathrm{~cm}\end{array}$ & $\begin{array}{c}\text { Inner } \\
\text { Mongolia }\end{array}$ & 2000 & $\begin{array}{c}40 \mathrm{~cm} \times 40 \\
\mathrm{~cm} \times \\
40 \mathrm{~cm}\end{array}$ & no & $\begin{array}{c}\text { regular } \\
\text { watering }\end{array}$ & 55.0 & 11.0 & 3.2 & 0 \\
\hline $\begin{array}{l}\text { DJHGQ- } \\
\text { SQLFP }\end{array}$ & April 2018 & $\begin{array}{l}\text { girths } 2.5 \mathrm{~cm} \text {, } \\
\text { heights } 200 \mathrm{~cm}\end{array}$ & $\begin{array}{c}\text { Inner } \\
\text { Mongolia }\end{array}$ & 1700 & $\begin{array}{c}40 \mathrm{~cm} \times 40 \\
\mathrm{~cm} \times \\
40 \mathrm{~cm}\end{array}$ & no & $\begin{array}{c}\text { regular } \\
\text { watering }\end{array}$ & 60.0 & 15.1 & 5.4 & 1.3 \\
\hline YZCMPD & April 2018 & $\begin{array}{l}\text { cutting } \\
\text { (1 year) }\end{array}$ & $\begin{array}{c}\text { Inner } \\
\text { Mongolia } \\
\end{array}$ & 300 & $\begin{array}{c}30 \mathrm{~cm} \times 30 \\
\mathrm{~cm}\end{array}$ & yes & $\begin{array}{c}\text { regular } \\
\text { watering }\end{array}$ & 18.2 & 11.2 & 10.0 & 10.0 \\
\hline CHZMPD & April 2018 & $\begin{array}{l}\text { grafting } \\
\text { (1 year) }\end{array}$ & $\begin{array}{c}\text { Inner } \\
\text { Mongolia }\end{array}$ & 600 & $\underset{\mathrm{cm}}{30 \mathrm{~cm} \times 30}$ & yes & $\begin{array}{c}\text { regular } \\
\text { watering }\end{array}$ & 94.0 & 94.0 & 94.0 & 94.0 \\
\hline
\end{tabular}

Note: ${ }^{1} \mathrm{SR}=$ survival rate ${ }^{2} \mathrm{CR}=$ conservation rate.

\subsection{Transplanting Experiment Using Different Seedlings}

In 2019, Populus euphratica seedlings from Inner Mongolia and the local field planting seedlings were transplanted in DJHGQ with no soil replacement but with regular watering. The results shown in Table 3 indicated that the survival rate of seedlings in 1st year were $10 \%$, and $15 \%$, respectively. After then, the conservation rate of Inner Mongolia seedlings in 2 nd, 3rd, year were decreased as $2.1 \%$ and $1.3 \%$, respectively. The conservation of rate of local field planting seedlings in 2nd, 3rd year decreased as $3.3 \%$ and $1.6 \%$, respectively. In the meanwhile, the self-fertile seedlings cultured with nutrition pot were transplanted in NYSFY and YHLC. The results shown in Table 3 indicated that the seedlings survival rate in NYSFY in 1st year was $95 \%$ and the survival rate in the third year is $90.0 \%$. In addition, 
and in 1st year, the seedlings survival rate in YHLC was 90\% and the survival rate in the third year is $89.5 \%$.

Table 3. Investigation on the survival rate of Populus euphratica.

\begin{tabular}{|c|c|c|c|c|c|c|c|c|c|c|c|}
\hline $\begin{array}{l}\text { Experimental } \\
\text { Sites }\end{array}$ & $\begin{array}{l}\text { Planting } \\
\text { Time }\end{array}$ & $\begin{array}{c}\text { Seedling } \\
\text { Specifications }\end{array}$ & $\begin{array}{l}\text { Seedling } \\
\text { Source }\end{array}$ & Number & $\begin{array}{c}\text { Land } \\
\text { Preparation }\end{array}$ & $\begin{array}{c}\text { Soil } \\
\text { Replacement }\end{array}$ & $\begin{array}{l}\text { Management } \\
\text { Measures }\end{array}$ & $\begin{array}{c}\mathrm{SR}^{1} \\
\text { 1st Year (\%) }\end{array}$ & $\begin{array}{c}\mathrm{CR}^{2} \\
\text { 2nd Year (\%) }\end{array}$ & $\begin{array}{c}\mathrm{CR}^{2} \\
\text { 3rd Year (\%) }\end{array}$ & $\begin{array}{c}\mathrm{CR}^{2} \\
\text { 4th Year (\%) }\end{array}$ \\
\hline \multirow{2}{*}{ DJHGQ } & April 2019 & $\begin{array}{l}\text { girths } 2 \mathrm{~cm} \text {, } \\
\text { heights } 200 \mathrm{~cm}\end{array}$ & $\begin{array}{c}\text { Inner } \\
\text { Mongolia }\end{array}$ & 15,000 & $\begin{array}{c}40 \mathrm{~cm} \times 40 \\
\mathrm{~cm} \times \\
40 \mathrm{~cm}\end{array}$ & no & $\begin{array}{c}\text { regular } \\
\text { watering }\end{array}$ & 10.0 & 2.1 & 1.3 & - \\
\hline & April 2019 & $\begin{array}{l}\text { girths } 1.5 \mathrm{~cm}, \\
\text { heights } 150 \mathrm{~cm}\end{array}$ & LFPS & 1900 & $\begin{array}{c}40 \mathrm{~cm} \times 40 \\
\mathrm{~cm} \times \\
40 \mathrm{~cm}\end{array}$ & No & $\begin{array}{c}\text { regular } \\
\text { watering }\end{array}$ & 15.0 & 3.3 & 1.6 & - \\
\hline NYSFY & April 2019 & $\begin{array}{c}\text { nutrition pot } \\
\text { seedlings ( } 2 \text { year) }\end{array}$ & self-fertile & 150,000 & $\begin{array}{c}30 \mathrm{~cm} \times 30 \\
\mathrm{~cm}\end{array}$ & yes & $\begin{array}{c}\text { regular } \\
\text { watering }\end{array}$ & 95.0 & 95.0 & 90.0 & - \\
\hline YHLC & May 2019 & $\begin{array}{c}\text { nutrition pot } \\
\text { seedlings (2 year) }\end{array}$ & self-fertile & 21,000 & $\begin{array}{c}30 \mathrm{~cm} \times 30 \\
\mathrm{~cm}\end{array}$ & yes & $\begin{array}{c}\text { regular } \\
\text { watering }\end{array}$ & 90.0 & 90.0 & 89.5 & - \\
\hline
\end{tabular}

Note: ${ }^{1}$ SR: survival rate; ${ }^{2}$ CR: Conservation rate.

\subsection{Transplanting Experiment Using Nutrition Pot Seedlings}

In 2020, large-scale introduction tests were carried out using self-fertile nutrition pot seedlings in XJHLC, DBX, and HSZSY (Table 4). In XJHLC, the seedlings were transplanted with no soil replacement but with regular watering. The results shown in Table 4 indicate that the survival rate of the seedlings in the first year was $85 \%$, and the conservation rate at the second year was $73 \%$. In DBX, the seedlings were transplanted with soil replacement and with regular watering. The results shown in Table 4 indicate that the survival rate of the seedlings in the first year was $96.3 \%$, and the conservation rate at the second year was $96 \%$. In HSZSY, the seedlings were transplanted with soil replacement and with regular watering. The results indicate that the survival rate of the seedlings in the first year were $97.0 \%$, and the conservation rate at the second year was $97.0 \%$.

Table 4. Investigation on the survival rate of Populus euphratica.

\begin{tabular}{|c|c|c|c|c|c|c|c|c|c|c|c|}
\hline $\begin{array}{l}\text { Experimental } \\
\text { Sites }\end{array}$ & $\begin{array}{l}\text { Planting } \\
\text { Time }\end{array}$ & $\begin{array}{c}\text { Seedling } \\
\text { Specifications }\end{array}$ & $\begin{array}{l}\text { Seedling } \\
\text { Source }\end{array}$ & Number & $\begin{array}{c}\text { Land } \\
\text { Preparation }\end{array}$ & $\begin{array}{c}\text { Soil } \\
\text { Replacement }\end{array}$ & $\begin{array}{l}\text { Management } \\
\text { Measures }\end{array}$ & $\begin{array}{c}\mathrm{SR}^{1} \\
\text { First Year (\%) }\end{array}$ & $\begin{array}{c}\mathrm{CR}^{2} \\
\text { Second Year (\%) }\end{array}$ & $\begin{array}{c}\mathrm{CR}^{2} \\
\text { Third Year (\%) }\end{array}$ & $\begin{array}{c}\mathrm{CR}^{2} \\
\text { Fourth Year (\%) }\end{array}$ \\
\hline XJHLC & May 2020 & $\begin{array}{c}\text { nutrition pot } \\
\text { seedlings (2 year) }\end{array}$ & self-fertile & 60,000 & $\begin{array}{c}40 \mathrm{~cm} \times 40 \mathrm{~cm} \\
\times 40 \mathrm{~cm}\end{array}$ & no & $\begin{array}{c}\text { regular } \\
\text { watering }\end{array}$ & 85.0 & 73.0 & - & - \\
\hline DBX & May 2020 & $\begin{array}{c}\text { nutrition pot } \\
\text { seedlings ( } 2 \text { year) }\end{array}$ & self-fertile & 4000 & $100 \mathrm{~cm} \times 100 \mathrm{~cm}$ & yes & $\begin{array}{c}\text { regular } \\
\text { watering }\end{array}$ & 96.3 & 96.0 & - & - \\
\hline HSZSY & May 2020 & $\begin{array}{c}\text { nutrition pot } \\
\text { seedlings ( } 2 \text { year) }\end{array}$ & self-fertile & 60,000 & $100 \mathrm{~cm} \times 100 \mathrm{~cm}$ & yes & $\begin{array}{c}\text { regular } \\
\text { watering }\end{array}$ & 97.0 & 97.0 & - & - \\
\hline
\end{tabular}

Note: ${ }^{1}$ SR: survival rate; ${ }^{2}$ CR: conservation rate.

\section{Discussion}

In 2017, the afforestation experiment started with seedlings from Xinjiang. In this batch, four different potential lethal factors-the experimental sites, seedling specifications, soil replacement, and management measures-were tested. The results shown in Table 1 indicate that, in the first year, the large-sized seedlings possessed higher survival rates. After that, the conservation rate in the second year showed different tendencies in XSQJD and XKGMPJD. In XSQJD, there was no significant difference $(p>0.05)$ between the large- and small-sized seedlings. After three years, all the seedlings in XSQJD died. The seedling conservation rate in XKGMPJD shows that the large-sized seedlings possessed a stronger vitality than the smaller ones. By comparing the growing states of the large-sized seedlings in FHDP and XKGMPJD with the same-sized seedlings in XSQJD, we found that proper land preparation and management measures are helpful for the survival of the seedlings $[17,18]$. In addition, in XKGMPJD, the sown seedlings cultured by seeds collected from Xinjiang showed a pleasing growth state, and the conservation rate before transplantation was over $95 \%$, which means that the seeds qualitatively collected from Xinjiang were available for further self-fertile experiments.

To rule out the possibility of seedling quality problems [7], in 2018, seedlings from Inner Mongolia were transplanted in DJHGQ at three different types of sites. The DJHGQXSTD site is a relatively flat area, and there are no dunes around. The DJHGQ-SQYFP 
site is a windward slope, and the DJHGQ-SQYFP site is a downwind slope. The results show that the survival rate in the first year in XSTD, SQYFP, and SQYFP followed a pattern from high to low. After that, almost all the seedlings at the three sites died. By analysis of the water level of XSTD, SQYFP, and SQYFP, we found that XSTD possessed a stable and relatively abundant water level of $2 \mathrm{~m}$, and the water level in SQYFP was 2-4 $\mathrm{m}$ and varied greatly with the seasons. This result indicates that proper soil moisture is necessary for the survival of Populus euphratica seedlings [19,20]. In addition, as seedlings on windward slopes face more windy weather, this increases the intensity of dehydration in seedling leaves [6]. Therefore, breeding here requires more precautions. In the meantime, using seedlings from Inner Mongolia, we also tried two different seedling techniques (cutting seedling and grafting seedling). The results show that the survival rate of the cutting seedling at the first year was $18.2 \%$, which is quite low for further promotion of afforestation technology. For the grafting seedling, the survival rate in the first year was $94 \%$, and the conservation rate stayed at $94 \%$ after 4 years. The successful grafting experiment indicates that a stable nutrient supply is one of the key factors for the higher survival rate of Populus euphratica. By comparing the seedling characteristics from the origin source (seedlings from Xinjiang and Inner Mongolia) and the self-fertile seedlings, we found that the introduced seedlings possessed weak vigor, and intact root systems were not retained. Wei et al. proved that plants are more vulnerable to disease when they are less active [14-16]. Therefore, the nutrition pot seedlings tried to overcome the above-mentioned challenges, and the results indicate that using proper tools to protect the root is one of the key factors to improve the survival rate of Populus euphratica. In addition, the grafting experiment, combined with our previous research, shows that a pathogenic fungus in the root soil could lead to a high death rate of Populus euphratica [4]. In this study, the major diseases and pests which always happened with Populus euphratica were stopped by specific fungicides and pesticides, following a principle of "prevention in the first and integrating with control" [21]. Therefore, a proper strategy for disease and insect pest control is another key factor to improve the survival rate of Populus euphratica.

In 2019, the survival rate of the seedlings from Inner Mongolia, local field planting seedlings and nutrition pot seedlings in DJHGQ, NYSFY, YHLC were tested (Table 3). The results indicate that the survival rate of the self-fertile nutrition pot seedlings in both NYSFY and YHLC was around 90\%, which meets the national criteria for successful afforestation. Therefore, large-scale afforestation experiments were conducted in 2019 in XJHLC, DBX, and HSZSY. In XJHLC, seedlings were planted with no land preparation, and proper land preparation was conducted in DCX and HSZSY. The results show that proper land preparation is needed to ensure a high survival rate. The survival rates in DBX and HSZSY were all over 95\% 2 years after transplantation. Our previous studies confirmed that the seedlings are less likely to die 2-3 years after transplantation [4]. Therefore, using self-fertile nutrition pot seedlings for the Populus euphratica afforestation in Yulin could be promoted as a success story.

\section{Conclusions}

In conclusion, after systemic investigation of six potential lethal factors, including seedling sources, experimental sites, seedling specifications, land preparations, soil replacement, and management measures in Populus euphratica afforestation, we found that the method of keeping a vigorous and complete root system is one of the key factors for successful Populus euphratica afforestation in the Mu Us Desert. In addition, using specific fungicides and pesticides, combined with a proper disease and insect strategy, is another key factor for successful Populus euphratica afforestation. In addition, a sufficient nutrition supply and proper land preparation are also important factors to improve the survival rate. Our study provides experience for the introduction of Populus euphratica in desert areas from the perspective of technology and practice. In the meantime, the successful introduction of Populus euphratica in the MUD provides a new guarantee for the desertification control project in the Yulin area from the perspective of biological diversity. 
However, the problem of biological diversity, mostly Pinus sylvestris and shrubs, in the $\mathrm{Mu}$ Us Desert remains serious. In order to consolidate the current forest conservation efforts, Populus euphratica, as an ideal candidate, has been considered since the 1950s. However, the low survival rate and conservation rate of Populus euphratica in the MUD stopped us from further large-scale introduction for over 70 years.

Author Contributions: Conceptualization, methodology and writing—original draft preparation, F.T.; writing — review and editing, B.G.; conceptualization and writing—review and editing, Z.D. All authors have read and agreed to the published version of the manuscript.

Funding: This research received no external funding.

Institutional Review Board Statement: Not applicable.

Informed Consent Statement: Not applicable.

Data Availability Statement: The data are available on request.

Acknowledgments: We are grateful to Xidong Tuo for the field technical support.

Conflicts of Interest: The authors declare no conflict of interest.

\section{References}

1. Feng, X.; Fu, B.; Lu, N.; Zeng, Y.; Wu, B. How ecological restoration alters ecosystem services: An analysis of carbon sequestration in China's loess Plateau. Sci. Rep. 2013, 3, 2846. [CrossRef]

2. Lai, Z.; Zhang, Y.; Liu, J.; Wu, B.; Qin, S.; Fa, K. Fine-root distribution, production, decomposition, and effect on soil organic carbon of three revegetation shrub species in northwest China. Ecol. Manag. 2016, 359, 381-388. [CrossRef]

3. Li, X.R.; Zhang, Z.S.; Huang, L.; Wang, X. Review of the ecohydrological processes and feedback mechanisms controlling sand-binding vegetation systems in sandy desert regions of China. Chin. Sci. Bull. 2013, 58, 1483-1496. [CrossRef]

4. Tuo, Y.; Dong, Z.; Wang, X.; Gao, B.; Zhu, C.; Tuo, F. Metagenomics reveal correlations between microbial organisms in soils and the health of Populus euphratica. Front. Microbiol. 2020, 11, 2095. [CrossRef] [PubMed]

5. Leszek, H.; Ewa, K.; Michał, W.; Agnieszka, H. Dynamics of the Natural Afforestation Process of a Small Lowland Catchment and Its Possible Impact on Runoff Changes. Sustainability 2021, 13, 10339.

6. Zhang, Q.A.; Chen, W. Ecosystem Water Use Efficiency in the Three-North Region of China Based on Long-Term Satellite Data. Sustainability 2021, 13, 7977. [CrossRef]

7. Yu, L.; Dong, H.; Li, Z.; Han, Z.; Korpelainen, H.; Li, C. Species-specific responses to drought, salinity and their interactions in Populus euphratica and P. pruinosa seedlings. J. Plant. Ecol. 2020, 13, 563-573. [CrossRef]

8. Schachtsiek, T.; Lamers, J.P.; Khamzina, A. Early survival and growth of six afforestation species on abandoned cropping sites in irrigated drylands of the Aral Sea Basin. Arid Land Res. Manag. 2014, 28, 410-427. [CrossRef]

9. Lamers, J.P.A.; Khamzina, A. Seasonal quality profile and production of foliage from trees grown on degraded cropland in arid Uzbekistan, Central Asia. J. Anim. Physiol. Anim. Nutr. 2010, 94, e77-e85. [CrossRef]

10. Keram, A.; Halik, Ü.; Keyimu, M.; Aishan, T.; Mamat, Z.; Rouzi, A. Gap dynamics of natural Populus euphratica floodplain forests affected by hydrological alteration along the Tarim River: Implications for restoration of the riparian forests. For. Ecol. Manag. 2019, 438, 103-113. [CrossRef]

11. Cao, B.; Song, L.H. Discussion on Afforestaion Techniques in Salt-alkaline Soil in Northern Ningxia. Adv. Mater. Res. 2012, 518, 5276-5280. [CrossRef]

12. Huang, X.Q.; Xin, C.L.; Hu, Z.M.; Li, G.T.; Zhang, T.H.; Zhao, W.; Li, S.G. Carbon storage of the forests and its spatial pattern in Nei Mongol, China. Chin. J. Plant. Ecol. 2016, 40, 327.

13. Xiao, J.; Eziz, A.; Zhang, H.; Wang, Z.; Tang, Z.; Fang, J. Responses of four dominant dryland plant species to climate change in the Junggar Basin, northwest China. Ecol. Evol. 2019, 9, 13596-13607. [CrossRef]

14. Wei, Z.; Gu, Y.A.; Friman, V.P.; Kowalchuk, G.A.; Xu, Y.C. Initial soil microbiome composition and functioning predetermine future plant health. Sci. Adv. 2019, 5, 759. [CrossRef]

15. Vorholt, J.A. Microbial life in the phyllosphere. Nat. Rev. Microbiol. 2012, 10, 828-840. [CrossRef]

16. Leff, J.W.; Del Tredici, P.; Friedman, W.E.; Fierer, N. Spatial structuring of bacterial communities within individual Ginkgo biloba trees. Environ. Microbiol. 2015, 17, 2352-2361. [CrossRef]

17. Zhao, P.; Qu, J.; Xu, X.; Yu, Q.; Jiang, S.; Zhao, H. Desert vegetation distribution and species-environment relationships in an oasis-desert ecotone of northwestern China. J. Arid Land 2019, 11, 461-476. [CrossRef]

18. Zhu, W.; Li, W.; Shi, P.; Cao, J.; Zong, N.; Geng, S. Intensified interspecific competition for water after afforestation with robinia pseudoacacia into a native shrubland in the taihang mountains, northern China. Sustainability 2021, 13, 807. [CrossRef]

19. Chen, Z.; Zhang, Z.Q.; Sun, G.; Chen, L.; Chen, S. Biophysical controls on nocturnal sap flow in plantation forests in a semi-arid region of northern china. Agr. For. Meteorol. 2020, 284, 107904. [CrossRef] 
20. Khamzina, A.; Lamers, J.; Martius, C. Above- and belowground litter stocks and decay at a multi-species afforestation site on arid, saline soil. Nutr. Cycl. Agroecosyst. 2016, 104, 187-199. [CrossRef]

21. Dong, A.Y.; Wang, Z.; Huang, J.J.; Song, B.A.; Hao, G.F. Bioinformatic tools support decision-making in plant disease management. Trends Plant. Sci. 2021, 26, 953-967. [CrossRef] [PubMed] 